\title{
Esophageal coin removal by emergency physicians: a continuous quality improvement project incorporating rapid sequence intubation
}

\author{
Rishi Bhargava, MD*; Lance Brown, MD, MPH
}

\section{ABSTRACT}

Objective: The objective of this study was to describe our experience removing esophageal coins from children in a tertiary care pediatric emergency department over a 4-year period.

Methods: We retrospectively reviewed a continuous quality improvement data set spanning October 1, 2004, through September 30, 2008.

Results: In 96 of 101 cases (95\%), emergency physicians successfully retrieved the coin. The median age of the children was 19 months (interquartile range [IQR] 13-43 months; range 4 months -12.8 years). The median time to removal of coin from initiation of intubation was 8 minutes (IQR 4-14 minutes; range 1-60 minutes). Coins were extracted using forceps only in 56 cases, whereas forceps and a Foley catheter were used in the remainder. Succinylcholine and etomidate were used in almost all cases for rapid sequence intubation prior to coin removal. Complications were identified in 46 cases: minor bleeding (13), lip laceration (7), multiple attempts (5), hypoxia (3), accidental extubation (3), dental injuries (3), bradycardia (2), coin advanced (1), right main-stem bronchus intubation (1), and other (8).

Conclusions: Emergency physicians successfully removed esophageal coins following rapid sequence intubation in most cases. Our approach may be considered for the management of pediatric esophageal coins, particularly in an academic pediatric emergency department.

\section{RÉSUMÉ}

Objectif : Nous avons voulu décrire l'expérience d'extraction de pièces de monnaie logées dans l'œsophage chez des enfants dans un service d'urgence pédiatrique de troisième ligne sur une période de quatre ans.

Méthode : Nous avons analysé de façon rétrospective un ensemble de données sur I'amélioration continue de la

qualité couvrant la période du $1^{\text {er }}$ octobre 2004 au 30 septembre 2008.

Résultats : Dans 96 des 101 cas (95\%), le médecin d'urgence a récupéré la pièce de monnaie.

L'âge médian des enfants était de 19 mois (intervalle interquartile [IIQ] $=13$ à 43 mois; plage $=4$ mois à 12,8 ans). Le délai médian à l'extraction de la pièce de monnaie, du début de l'intubation était de 8 minutes (IIQ = 4 à 14 minutes; plage $=1$ à 60 minutes). Les pièces ont été extraites en utilisant uniquement des forceps dans 56 cas et en utilisant des forceps et une sonde de Foley dans le reste des cas. On a administré de la succinylcholine et de l'étomidate dans presque tous les cas d'intubation en séquence rapide avant l'extraction de l'objet. Des complications ont été observées dans 46 cas : saignements mineurs (13), lacération de la lèvre (7), tentatives multiples (5), hypoxie (3), extubation accidentelle (3), traumatismes dentaires (3), bradycardie (2), avancement de la pièce (1), intubation de la bronche souche droite (1), autres (8).

Conclusion : Les médecins d'urgence ont extrait des pièces de monnaie logées dans l'œsophage après une intubation en séquence rapide dans la plupart des cas. Notre méthode peut être envisagée pour l'extraction de pièces de monnaie coincées dans l'oesophage chez les enfants, particulièrement dans un service d'urgence pédiatrique d'un hôpital universitaire.

Keywords: airway, continuous quality management, esophagus, foreign body, intubation

The ingestion of coins by children is a common phenomenon. ${ }^{1}$ Fortunately, many swallowed coins will traverse the entire digestive tract and pass without complication..$^{2-4}$ However, some coins become lodged in the esophagus, ${ }^{5,6}$ causing throat irritation, gagging,

From the *Division of Pediatric Emergency Medicine, Department of Emergency Medicine, Loma Linda Medical University Medical Center and Children's Hospital, Loma Linda, CA.

Correspondence to: Dr. Rishi Bhargava, Loma Linda Medical University Medical Center and Children's Hospital, 11234 Anderson Street, A-108, Loma Linda, CA 92354; rishbhar@yahoo.com.

This article has been peer reviewed. 
and vomiting. 2,7 Life-threatening complications are rare, but esophageal perforation, extraluminal coin migration, tracheoesophageal fistula, and fatal aortoesophageal fistula have been reported. 8,9 Esophageal coins can be removed with Magill forceps, a Foley catheter, endoscopy, and airway bougienage to advance the coin into the stomach, where subsequent spontaneous passage is the expected outcome. ${ }^{3-7,10-13}$ Historically, at our institution, pediatric surgeons, otolaryngologists, and pediatric gastroenterologists have performed the removal of esophageal coins. In mid-2003, our group of general and pediatric emergency physicians expressed interest in removing these coins in the emergency department (ED). We developed a continuous quality improvement (CQI) project and have previously published a pilot study based on the first 13 patients. ${ }^{14}$ The objective of this article is to describe our experience with removing esophageal coins over the subsequent 4 years.

\section{PATIENTS AND METHODS}

We retrospectively reviewed a pre-existing CQI data set from our tertiary care university-based pediatric ED spanning October 1, 2004, through September 30, 2008. Our facility has an annual volume of 21,500 pediatric visits and 38 hours of attending physician coverage daily. Approximately 18 pediatric emergency medicine-trained physicians and 12 emergency medicine physicians worked in our department during the study.

Children younger than 18 years with a relatively brief duration of symptoms (ie, the time of coin ingestion was relatively certain and less than 72 hours, with a preference for less than 24 hours) were eligible. All patients with radiographically documented esophageal coins who underwent attempted coin removal by an emergency physician were included. Typically, these coins were in the upper third of the esophagus. Emergency physicians performed attempted removal following previously published guidelines. ${ }^{14}$ The recommendations included rapid sequence intubation (RSI) followed by direct visualization of the esophagus larygoscopically. If the coin was visible, Magill forceps were to be used. Otherwise, a Foley catheter was to be passed beyond the coin, the balloon inflated, and the catheter withdrawn. ${ }^{12,14,15}$

Emergency physicians recorded key data on CQI forms that included the patient's date of birth, date of visit, gender, foreign body description, immediate complications, and telephone contact information. Hospital records were reviewed to ascertain whether the patient had been transferred from another ED, key time points including the duration since coin ingestion and the duration of fasting (nihil per os) prior to the procedure, the presence of a respiratory care practitioner, medications administered, method of removal, and the timing of intubation, coin removal, extubation, and discharge from the ED. Families were telephoned at follow-up to identify any residual symptoms or complications. If families could not be reached after multiple attempts, then the medical record was reviewed to identify return visits to our facility.

To assess the reliability of our data abstraction, 11 charts were selected at random and independently reviewed by a second data abstractor blinded to the first review. ${ }^{16,17}$ Interobserver reliability was assessed using the concordance rate and unweighted kappa statistic.

\begin{tabular}{|c|c|}
\hline \multicolumn{2}{|l|}{ Age of patients } \\
\hline Median & $19 \mathrm{mo}$ \\
\hline IOR & $13-43 \mathrm{mo}$ \\
\hline Range & $4 \mathrm{mo}-12.8 \mathrm{yr}$ \\
\hline Sex & $n(\%)$ \\
\hline Boys & $62(61)$ \\
\hline Girls & 39 (39) \\
\hline \multicolumn{2}{|l|}{ Type of coin, $n$} \\
\hline Penny & $56(55)$ \\
\hline Quarter & $17(17)$ \\
\hline Nickel & $14(14)$ \\
\hline Dime & $4(4)$ \\
\hline Gold dollar coin & $1(1)$ \\
\hline Peso & $1(1)$ \\
\hline Nickel and penny & $1(1)$ \\
\hline 2 quarters & $1(1)$ \\
\hline 2 nickels & $1(1)$ \\
\hline Not available & $5(5)$ \\
\hline Success rate & $96(95)$ \\
\hline Consultation rate & $5(5)$ \\
\hline \multicolumn{2}{|l|}{ Disposition } \\
\hline Home & $85(84)$ \\
\hline Observation & $12(12)$ \\
\hline Admission & $4(4)$ \\
\hline
\end{tabular}


Table 2. Description of five cases in which coins were not removed by emergency physician

\begin{tabular}{|c|c|c|c|c|c|c|c|c|}
\hline Age (mo) & Gender & $\begin{array}{l}\text { Time to presentation } \\
\text { (hr) }\end{array}$ & Location* & Complication & $\begin{array}{l}\text { Outcome } \\
\text { per family }\end{array}$ & $\begin{array}{l}\text { Removal } \\
\text { method }\end{array}$ & $\begin{array}{c}\text { Physician } \\
\text { number }\end{array}$ & Consultant \\
\hline 14 & F & 3.5 & Thoracic inlet & $\begin{array}{l}\text { Tooth } \\
\text { chipped }\end{array}$ & $\begin{array}{l}\text { "No } \\
\text { problems" }\end{array}$ & $\mathrm{F}$ & 4 & $\begin{array}{l}\text { Pediatric } \\
\text { surgeon }\end{array}$ \\
\hline 11 & M & 48 & Above clavicle & None noted & $\begin{array}{l}\text { "No } \\
\text { problems" }\end{array}$ & $F$ & 5 & ENT \\
\hline 9 & M & 6 & $\mathrm{C} 7 / \mathrm{T} 1$ & None noted & $\begin{array}{l}\text { "No } \\
\text { problems" }\end{array}$ & $\mathrm{FC}$ & 14 & ENT \\
\hline 51 & $\mathrm{~F}$ & 11.5 & $\begin{array}{c}\text { Upper } \\
\text { esophagus }\end{array}$ & None noted & NR & $\mathrm{FC}$ and $\mathrm{F}$ & 5 & ENT \\
\hline 4 & M & ND & Midesophagus & None noted & NR & $\mathrm{FC}$ and $\mathrm{F}$ & 6 & ENT \\
\hline
\end{tabular}

Descriptive statistics were generated using functions provided in Excel 2008 (Microsoft Corporation, Redmond, WA), summarized as medians and interquartile ranges (IQRs). Our Institutional Review Board approved this study.

\section{RESULTS}

During the study period, 15 physicians (12 pediatric emergency medicine and 3 general emergency physicians) attempted or directly supervised emergency medicine residents or pediatric emergency fellows in the removal of esophageal coins from 101 children. The median age of the children was 19 months (IQR 13-43 months; range 4 months- 12.8 years), and most (62) were boys. The majority (86) had been transferred from another hospital. The median time from coin ingestion to presentation at our ED was 5 hours (IQR 3.7-7.1 hours; range 0.5-96 hours). Cases had fasted a median of 8.5 hours (IQR 7-11 hours; range 2.5-19.5 hours) prior to the procedure (Table 1 ).

In 96 cases (95\%), emergency physicians successfully retrieved the coins. In the five remaining cases, an otolaryngologist or pediatric surgeon eventually removed the coin using forceps and/or a Foley catheter (Table 2). Pediatric gastroenterology was consulted in one additional case after minimal bleeding was noted after coin removal and extubation. RSI using paralytics (succinylcholine, 96; vecuronium, 9; rocuronium, 3) and sedation (etomidate, 95; propofol, 12; midazolam, 12; morphine 1) was used in all cases, and atropine premedication was used in 84 cases. The median age at which atropine was not used was 2.3 years (IQR 1.84.6 years; range $0.7-12.75$ years). A variety of coins were removed. Three children each had two coins removed.

The median time to removal of the coin from initiation of intubation was 8 minutes (IQR 4-14 minutes; range 1-60 minutes). In the 52 cases where the coin was visualized at laryngoscopy, the median time to removal was 5 minutes (IQR 2-12 minutes; range 1-39 minutes). When the coin was not visualized, the median time to removal was 12 minutes (IQR 6.5-21.75 minutes; range 3-60 minutes). Nine procedures lasted longer than 30 minutes (Table 3 ). The median time from intubation to extubation was 15 minutes (IQR 9-24 minutes; range 2-93 minutes). The median time spent in the ED was 5 hours (IQR 3.4-6.4 hours; range 1.5-45 hours). Forceps were the sole means of extraction in 56 cases, whereas a Foley catheter and forceps were used in the remainder. A respiratory care practitioner was present for 92 cases. Five children were not intubated. One child was sedated and ventilated through a pre-existing tracheostomy. In the other four children, the coin was visualized and removed at laryngoscopy prior to intubation. After the attempted removal of the esophageal coin, 48 children received additional medications. Dexamethasone was given to 42 children, ondansetron was given to 4 children, and dexamethasone and racemic epinephrine were given to 2 children.

Mild bleeding was the most commonly documented complication from the procedure (Table 4). Other complications included accidental extubation, hypoxia, dental trauma, and bradycardia.

Fifty-eight families were contacted in follow-up a median of 111 days (IQR 22-351 days; range 1-1011 days) after the index visit. In four cases, the family 
Table 3. Esophageal coin removal lasting $\mathbf{3 0}$ minutes or longer

\begin{tabular}{|c|c|c|c|c|c|c|c|c|c|}
\hline $\begin{array}{l}\text { Time to } \\
\text { removal } \\
\text { (min) }\end{array}$ & Age & Gender & $\begin{array}{l}\text { Time to ED } \\
\text { (hr) }\end{array}$ & Location of coin* & Follow-up & Complications & $\begin{array}{l}\text { Method of } \\
\text { removal }\end{array}$ & $\begin{array}{l}\text { Coin } \\
\text { visible? }\end{array}$ & Coin type \\
\hline 30 & 10 mo & M & 96 & Sternal notch & Not available & Right main stem & $\mathrm{F}, \mathrm{FC}$ & No & Penny \\
\hline 50 & $11 \mathrm{mo}$ & $\mathrm{F}$ & 7.5 & Clavicles & Sore throat for $4 \mathrm{~d}$ & Not available & $F, F C$ & No & Penny \\
\hline 39 & $32 \mathrm{mo}$ & $\mathrm{F}$ & 5.5 & Lower esophagus & Not available & $\begin{array}{l}\text { Accidental } \\
\text { extubation }\end{array}$ & $\mathrm{F}, \mathrm{FC}$ & No & Penny \\
\hline 45 & $14 \mathrm{mo}$ & M & 96 & Upper esophagus & Not available & $\begin{array}{c}\text { Multiple attempts, } \\
\text { hard to see }\end{array}$ & $\mathrm{F}, \mathrm{FC}$ & No & Penny \\
\hline 36 & $7 \mathrm{mo}$ & M & 5.25 & $\begin{array}{l}\text { Proximal } \\
\text { esophagus }\end{array}$ & No complications & $\begin{array}{c}\text { Multiple attempts, } \\
\text { hard to see }\end{array}$ & $\mathrm{F}, \mathrm{FC}$ & No & Penny \\
\hline 43 & 19 mo & $\mathrm{F}$ & 96 & Clavicles & Not available & Hypoxia & $F, F C$ & No & Penny \\
\hline 60 & $5.6 \mathrm{yr}$ & $\mathrm{F}$ & 3.5 & $\begin{array}{l}\text { Proximal } \\
\text { esophagus }\end{array}$ & Not available & $\begin{array}{c}\text { Multiple attempts, } \\
\text { hard to see }\end{array}$ & $\mathrm{F}, \mathrm{FC}$ & No & Penny \\
\hline 30 & $6.7 \mathrm{yr}$ & M & 4.75 & Upper esophagus & Not available & None & $F, F C$ & No & Quarter \\
\hline 39 & $5 \mathrm{yr}$ & $F$ & Unknown & $\begin{array}{l}\text { Cervical } \\
\text { esophagus }\end{array}$ & No complications & $\begin{array}{l}\text { Accidentlly } \\
\text { extubated }\end{array}$ & $\mathrm{F}, \mathrm{FC}$ & No & Nickel \\
\hline
\end{tabular}

$\mathrm{ED}=$ emergency department; $\mathrm{F}=$ forceps; $\mathrm{FC}=$ Foley catheter.

*Physician description in the medical records.

described a sore throat lasting 0.5 to 2 days. Three other families described minor complaints: one child refused solids for a couple of days, one had neck pain for 2 days, and one had a cough for 2 days.

The medical records at our facility were reviewed for the 43 cases that could not be reached by telephone calls. No follow-up visits were identified for 35 of these

\begin{tabular}{lc}
$\begin{array}{l}\text { Table 4. Physician-identified complications of esophageal } \\
\text { coin removal }\end{array}$ & $\begin{array}{c}\text { Number of } \\
\text { children }\end{array}$ \\
\hline Complication & 55 \\
None & 13 \\
Mild bleeding & 7 \\
Lip laceration & 5 \\
Multiple attempts; difficult to see & 4 \\
Unable to remove coin & 3 \\
Accidentally extubated & 2 \\
Bradycardia with Foley catheter insertion & 2 \\
Hypoxia & 1 \\
Tooth chipped; unable to remove coin & 1 \\
Tooth contusion & 1 \\
Lost baby tooth & 1 \\
Prolonged intubation & 1 \\
Coin pushed down further on initial attempt & 1 \\
Pharyngeal irritation & 1 \\
Minimal edema & 1 \\
Prolonged paralysis, hypoxia & 1 \\
Rash & 1 \\
Right mainstem intubation during the & \\
procedure &
\end{tabular}

cases. Seven patients returned to the ED or outpatient clinic for unrelated reasons. One patient ingested another coin 2 months after the first visit, and that coin was removed uneventfully by an emergency medicine physician. Prior to the removal, the chest radiology was remarked as being uneventful other than the noted foreign body. In total, three patients had normal chest radiographs in follow-up, and one patient had radiographic evidence of pneumonia 7 months after the initial visit.

RSI medications used in 11 cases were reviewed by a second abstracter and found to have 100\% concordance and a kappa of 1 .

\section{DISCUSSION}

Over a 4-year period, our emergency physicians attempted esophageal coin removal in 101 cases and were successful $95 \%$ of the time. From our review of the literature, it appears that few emergency physicians attempt esophageal coin removal. A group in Minnesota described their experience passing a bougienage in awake children with the goal of advancing the coin into the stomach. ${ }^{18,19}$ In one study, they reported a $100 \%$ success rate with 31 cases. In this series, they reported no serious complications. However, in two cases, coins remained in the stomach after 2 weeks and were subsequently removed endoscopically. In their follow-up study, they successfully managed 338 of 355 (95\%) pediatric esophageal coins. 
In this series, three patients required subsequent endoscopic coin removal. In these two reports, the objective was to pass the coin into the stomach. Although most patients uneventfully pass subdiaphragmatic coins, a potential, but rare, complication of this method is cecal retention that mimics appendicitis. ${ }^{20}$

Our study differs from the Minnesota method in that a majority of our patients were intubated and had their coins removed. This method has been described in the literature but is typically performed in the operating suite. The use of Magill forceps and Foley catheters has been described in the past. ${ }^{6,11,15,21-23}$ Mahafza described a series of 75 patients who were taken to the operating room suite and given gas induction, and the coin was removed by an otolaryngologist with Magill forceps if visualized. ${ }^{6}$ If the coin was not visualized, the patient was intubated by an anesthesiologist and the coin was removed by rigid esophagoscopy. Janik and Janik described 36 children who were intubated in the operating room suite and had pediatric surgeons use a combination of Foley catheters and forceps for the removal of the coins. ${ }^{11}$

In our study, three cases of double coins were managed. One case had a tooth contusion, another had an accidental extubation during the procedure, and the third child had no complications during the procedure. Previous studies have excluded multiple coin ingestions. ${ }^{13,18,19,24,25}$ Complications have been reported in cases of multiple coin ingestions. ${ }^{26}$ There are, however, few reports describing multiple coin ingestions. ${ }^{19}$

At our institution, we can consult subspecialists following a failed esophageal foreign body removal. Nine cases required more than 30 minutes to complete, which might strain the resources of some EDs.

Our study is limited by not having all cases entered into the CQI database. Many cases were lost to telephone follow-up, limiting our ability to identify long-term complications. Delayed follow-up with some families suggests that minor complaints and complications may have been forgotten and therefore not reported. We were unable to search health records at other facilities to identify complications presenting elsewhere.

\section{CONCLUSION}

Emergency physicians successfully removed the vast majority of esophageal coins in children. Our approach including RSI may be considered for the management of esophageal coins, particularly in an academic pediatric ED.

Competing interests: None declared.

\section{REFERENCES}

1. Bronstein AC, Spyker DA, Cantilena LR Jr, et al. 2006 annual report of the American Association of Poison Control Centers' National Poison Data System (NPDS). Clin Toxicol (Phila) 2007;45:815-917.

2. Cheng $W$, Tam PK. Foreign-body ingestion in children experience with 1,265 cases. 7 Pediatr Surg 1999;34:1472-6.

3. Soprano JV, Fleisher GR, Mandl KD. The spontaneous passage of esophageal coins in children. Arch Pediatr Adolesc Med 1999;153:1073-6.

4. Sharieff GQ, Brousseau TJ, Bradshaw JA, et al. Acute esophageal coin ingestions: is immediate removal necessary? Pediatr Radiol 2003;33:859-63.

5. Hostetler MA, Barnard JA. Removal of esophageal foreign bodies in the pediatric ED: is ketamine an option? $A m \mathcal{F}$ Emerg Med 2002;20:96-8.

6. Mahafza TM. Extracting coins from the upper end of the esophagus using a Magill forceps technique. Int 7 Pediatr Otorbinolaryngol 2002;62:37-9.

7. Conners GP. A literature-based comparison of three methods of pediatric esophageal coin removal. Pediatr Emerg Care 1997;13:154-7.

8. Tucker JG, Kim HH, Lucas GW. Esophageal perforation caused by coin ingestion. South Med 7 1994;87:269-72.

9. Macpherson RI, Hill JG, Othersen HB, et al. Esophageal foreign bodies in children: diagnosis, treatment, and complications. A7R Am 7 Roentgenol 1996;166:919-24.

10. Bacli AE, Eren S, Eren MN. Esophageal foreign bodies under cricopharyngeal level in children: an analysis of 1116 cases. Interact Cardiovasc Thorac Surg 2004;3:14-8.

11. Janik JE, Janik JS. Magill forceps extraction of upper esophageal coins. 7 Pediatr Surg 2003;38:227-9.

12. Mason SM. Pharyngeal coin removal in children. 7 Accid Emerg Med 1997;14:175-6.

13. Calkins CM, Christians KK, Sell LL. Cost analysis in the management of esophageal coins: endoscopy versus bougienage. 7 Pediatr Surg 1999;34:412-4.

14. Vargas EJ, Mody AP, Kim TY, et al. The removal of coins from the upper esophageal tract of children by emergency physicians: a pilot study. CFEM 2004;6:434-40.

15. Schunk JE, Harrison AM, Corneli HM, et al. Fluoroscopic Foley catheter removal of esophageal foreign bodies in children: experience with 415 episodes. Pediatrics 1994;94: 709-14.

16. Random.org. Integer generator. Available at: http://www. random.org/integers/. (accessed April 27, 2010).

17. Gilbert EH, Lowenstein SR, Koziol-McLain J, et al. Chart reviews in emergency medicine research: where are the methods ? Ann Emerg Med 1996;27:305-8. 
18. Emslander HC, Bonadio W, Klatzo M. Efficacy of esophageal bougienage by emergency physicians in pediatric coin ingestion. Ann Emerg Med 1996;27:726-9.

19. Arms JL, Mackenberg-Mohn MD, Bowen MV, et al. Safety and efficacy of a protocol using bougienage or endoscopy for the management of coins acutely lodged in the esophagus: a large case series. Ann Emerg Med 2008;51:367-72. [Epub 2007 Oct 15].

20. Betz JS, Hampers LC. Cecal retention of a swallowed penny mimicking appendicitis in a healthy 2 year old. Pediatr Emerg Care 2004;20:525-7.

21. Bigler FC. The use of a Foley catheter for removal of blunt foreign bodies from the esophagus. 7 Thorac Cardiovasc Surg 1966;51:759-60.
22. Brown LP. Blind esophageal coin removal using a Foley catheter. Arch Surg 1968;96:931-2.

23. Cetinkursun S, Sayan A, Demirbag S, et al. Safe removal of upper esophageal coins by using Magill forceps: two centers' experience. Clin Pediatr (Phila) 2006;45:71-3.

24. Amin MR, Buchinsky FJ, Gaughan JP, et al. Predicting outcome in pediatric coin ingestion. Int 7 Pediatr Otorbinolaryngol 2001;59:201-6.

25. Dahshan AH, Kevin Donovan G. Bougienage versus endoscopy for esophageal coin removal in children. 7 Clin Gastroenterol 2007;41:454-6.

26. Jona JZ, Glicklich M, Cohen RD. The contraindications for blind esophageal bouginage for coin ingestion in children. $\mathcal{F}$ Pediatr Surg 1988;23:328-30. 